\title{
Studies on Growth of Softwood Grafts in Different Custard Apple (Annona squamosa L.) Cultivars
}

\author{
R.S. Pawar, A.R. Jadhav* and P.S. Urade \\ Department of Horticulture, College of Agriculture, Latur \\ Vasantrao Naik Marathwada Krishi Vidyapeeth, Parbhani- 431402 (M.S.) India \\ *Corresponding author
}

\section{A B S T R A C T}

Keywords

Softwood grafting, Growth, Custard apple

Article Info

Accepted:

15 February 2019

Available Online:

10 March 2019
The present investigation entitled Studies on growth of softwood grafts in different custard apple (Annona squamosa L.) cultivars was undertaken at Custard Apple Research Station, Ambajogai during 2016-2017, to evaluation of softwood grafts for growth of different cultivars. The experiment was laid out in a Randomized Block Design with 07 treatments viz. Dharur-6, Dharur-3, TP-7, Balanagar, ArkaSahan, Red Sitaphal and Purandar Local at nursery stage with three replications. The results indicated that, the highest length of sprout $(37.84 \mathrm{~cm})$ after 120 days of grafting, graft height $(41.84 \mathrm{~cm})$, number of leaves graft $^{-1}$ (43.75) after 120 days of grafting, leaf area $\left(30.27 \mathrm{~cm}^{2}\right)$ after 120 days of grafting, length of roots $(30.83 \mathrm{~cm})$ and number of secondary roots $(53.52)$ were recorded in treatment $\mathrm{T}_{5}$ (ArkaSahan). Therefore, treatment $\mathrm{T}_{5}$ (ArkaSahan) have performed better for most of the traits under study.

\section{Introduction}

Custard apple (Annona squamosa L.) is an important dry land fruit of India. It belongs to family Annonaceae. The genus includes more than 100 species of which five produce edible fruits. Among these Annona squamosa L.(Custard apple) Annona reticulate (Bullock heart, Ramphal) and Annona cherimola (Hanu-manphal) are commercially important. It is most favored monoecious fruit also known as a Sitaphal, Sugar apple, Sweet soap in India.Annona squamosa L. originated in Central America from there, it was distributed to Mexico and Tropical America (Popenoe,
1974).The total area under cultivation of custard apple in India is 37 thousand hectare and production is around 291thousand MT according to NHB (Anonymous, 2017). Custard apple is suitable to cultivate in dry climate. It can withstand mild frost. The root system is confined to relatively shallow layers and therefore, these do not require deep soil. Annonaceous fruits are mainly propagated through seed and therefore, there exists a great variation in respect of growth, yield and fruit quality amongst the trees grown in the orchard. At present very few nurseries are producing grafts of custard apple through softwood grafting which is very easy to 
perform. There are several commercial varieties of custard apple like ArkaSahan, Balanagar, TP-7, Purandar Local, Red Sitaphal, Dharur-3 Dharur-6, Annona and Finger print which are grown in different parts of India.

\section{Materials and Methods}

An experiment on custard apple cultivars were conducted at Custard Apple Research Station, Ambajogai during 2016-2017. The experiment was laid out in a Randomized Block Design with 07 treatments viz., Dharur6, Dharur-3, TP-7, Balanagar, ArkaSahan, Red Sitaphal and Purandar Local at nursery stage with three replications.

The softwood grafting was done on the healthy rootstock seedling with different cultivars. The observations on growth of grafting were recorded at 15 days intervals to a period of three months. The statistical analysis of the data in respect of growth of grafts was done according to the standard procedure given by Panse and Sukhatme (1996).

\section{Results and Discussion}

\section{Growth of softwood grafting in different cultivars of custard apple}

It is revealed from the data (Table 1 and Figure 1), the significantly highest length of sprout $(37.84 \mathrm{~cm})$ after 120 days of grafting, graft height $(41.84 \mathrm{~cm})$, number of leaves graft $^{-1}$ (43.75) after 120 days of grafting, leaf area $\left(30.27 \mathrm{~cm}^{2}\right)$ after 120 days of grafting, length of roots $(30.83 \mathrm{~cm})$ and number of secondary roots (53.52) werenoted under the treatment $\mathrm{T}_{5}$ (ArkaSahan) as compared to other cultivars. These variations could be attributed due to its earlier sprouting of grafts, more number of leaves and maximum leaf area per leaf and per graft, which might have produced more amounts of carbohydrates required for vegetative growth resulting into maximum height of scion.

Table.1 Growth of softwood grafting in different cultivars of custard apple

\begin{tabular}{|c|c|c|c|c|c|c|}
\hline Treatments & $\begin{array}{c}\text { Length of } \\
\text { sprout }(\mathrm{cm}) \\
120 \text { days of } \\
\text { grafting }\end{array}$ & $\begin{array}{l}\text { Graft } \\
\text { height } \\
\text { (cm) }\end{array}$ & $\begin{array}{l}\text { Number of } \\
\text { leaves graft } \\
120 \text { days of } \\
\text { grafting }\end{array}$ & $\begin{array}{l}\text { Leaf area } \\
\left(\mathrm{cm}^{2}\right) \\
120 \text { days of } \\
\text { grafting }\end{array}$ & $\begin{array}{l}\text { Lengt } \\
h \text { of } \\
\text { roots } \\
(\mathrm{cm})\end{array}$ & $\begin{array}{c}\text { Number } \\
\text { of } \\
\text { secondar } \\
y \text { roots }\end{array}$ \\
\hline $\mathbf{T}_{1}$ & 32.37 & 37.40 & 39.82 & 26.26 & 27.22 & 48.58 \\
\hline $\mathbf{T}_{2}$ & 32.10 & 37.10 & 39.93 & 26.92 & 26.60 & 48.60 \\
\hline $\mathbf{T}_{3}$ & 29.06 & 33.16 & 37.14 & 25.25 & 23.99 & 46.35 \\
\hline $\mathbf{T}_{4}$ & 31.07 & 36.17 & 40.38 & 27.27 & 24.69 & 47.58 \\
\hline$T_{5}$ & 37.84 & 41.84 & 43.75 & 30.27 & 30.83 & 53.52 \\
\hline $\mathbf{T}_{6}$ & 27.05 & 31.07 & 35.11 & 25.53 & 23.67 & 42.56 \\
\hline $\mathbf{T}_{7}$ & 35.96 & 40.56 & 41.51 & 29.43 & 28.33 & 52.36 \\
\hline S.E. \pm & 0.02 & 0.75 & 0.03 & 0.15 & 0.43 & 0.22 \\
\hline C.D at $5 \%$ & 0.06 & 2.25 & 0.09 & 0.46 & 1.33 & 0.68 \\
\hline
\end{tabular}




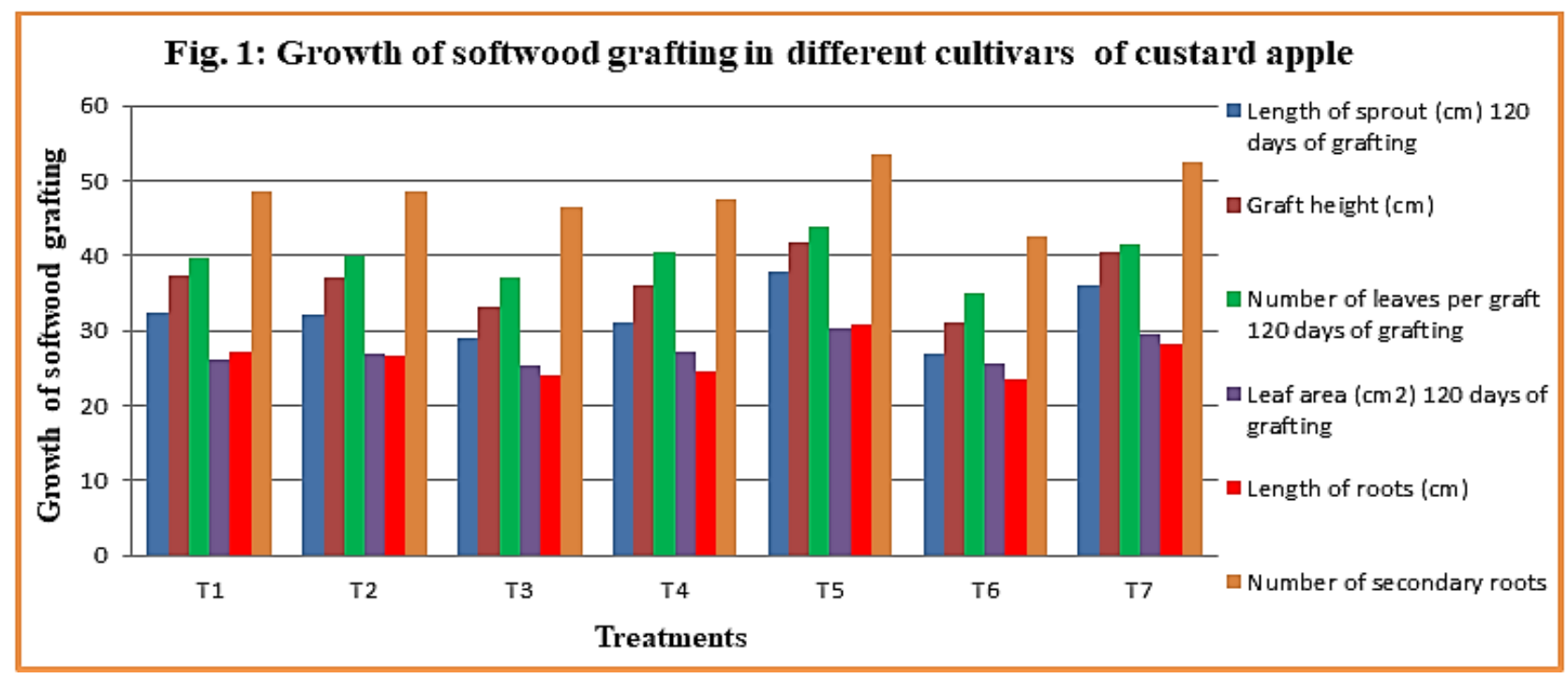

This result was similar reported by Joshi et al. (2011)in custard apple, Islam et al. (2004) in mango, Gadekaret al. (2010) in jamun and Mulla et al., (2011) in jamun. In respect to number of leaves reported by Das et al. (2006) and Ghosh et al. (2010) in sapota and in length of root reported by Sardar et al. (1991) in cashew and Roshan et al.(2013) in aonla

In conclusion, the critical evaluation of results of the present study indicated that, considering the overall performance of growth of different custard apple cultivars studied, treatment $\mathrm{T}_{5}$ (Arka Sahan) have performed better for most of the traits under study. Arka Sahan showed significantly superior results in terms of growth of softwood grafting like length of sprout after 120 days of grafting, graft height, number of leaves graft $^{-1}$ after 120 days of grafting, leaf area after 120 days of grafting, length of roots and number of secondary roots.

\section{References}

Anonymous, 2017.Area and Production of Horticulture Crops in India. Indian Horticulture Database, National Horticulture Board.

Das, B.K., Das, J.N. and Acharya, G.C., 2006.
Effect of potting media on air-grafting of five sapota varieties. The Orissa Journal of Horticulture, 34(2): 18-22.

Gadekar, A, Bharad S.G, Mane, V.P. and Patil, S., 2010.Seasonl variation in success of softwood grafting in jamun under Akola condition. The Asian Journal Horticulture, 5(2): 266-268.

Ghosh, S.N., Beral, B., Royl, S. and Banik, B.C., 2010.Effect of cultivars and season on grafting success in sapota under Paschim Midnapur condition of West Bengal. Journal of Horticulture Science, 5(2): 138-139.

Islam, M.N., Rahim, M.A. and Farooque, A.M., 2004. Standardization of time and grafting techniques in mango under Bangladesh condition. Asian Journal of Plant Science, 3(3): 378-386.

Joshi, P.S., Jadhao, B.J. and Chaudhari, G.V., 2011.Studies on vegetative propagation in custard apple. The Asian Journal of Hort., 6(1): 261-263.

Mulla, B.R., Angadi, S.G., Mathad, J.C., Patil, V.S. and Mummigatti, U.V., 2011.Studies on softwood grafting in jamun (Syzygium cumini Skeels). Karnataka Journal Agric. Sci., 24(3): 366-368.

Panse, V.G. and Sukhatme, P.V., 1996. Statistical methods for Agricultural 
workers. I.C.A.R. Publication, New Delhi: 381.

Popenoe, G.J., 1974. Status of annona cultural in South Florida. Prop. Florida state. Hort. Society, 87: 342-344.

Roshan, R.K., Pebam, N. and Panchbhai, D.M., 2013. Effect of rootstock age and time of softwood grafting on grafting Success in aonla (Emblica officinalis). Acta horticulture: 975.43.

Sardar, C., Prabhakar R., Ravishankar, C. and Subba, R.N., 1991.Studies on softwood grafting in cashew. South Indian Hort., 39(3): 119-123.

\section{How to cite this article:}

Pawar, R.S., A.R. Jadhav and Urade, P.S. 2019. Studies on Growth of Softwood Grafts in Different Custard Apple (Annona squamosa L.) Cultivars. Int.J.Curr.Microbiol.App.Sci. 8(03): 1801-1804. doi: https://doi.org/10.20546/ijcmas.2019.803.211 